\title{
The distribution and status of Worthen's Sparrow Spizella wortheni: a review
}

\author{
DAVID C. WEGE, STEVE N. G. HOWELL and ANDRÉS M. SADA
}

\begin{abstract}
Summary
Originally described last century from New Mexico, U.S.A., Worthen's Sparrow Spizella wortheni has subsequently been recorded from just eight states in Mexico centred on the interior of the north-east of the country. Records during the last 30 years originate from just Coahuila and Nuevo León, with those during the last to years exclusively from two small areas in south-eastern Coahuila and western Nuevo León: it appears that this poorly known species has been suffering a range contraction owing to the widespread destruction of its shrubby (mesquite or yucca-juniper) grassland habitat. Little detail is known of its specific requirements, local movements, or even its distribution, and it is proposed that Worthen's Sparrow be formally recognized as a threatened species.
\end{abstract}

Originalmente descrito el siglo pasado a partir de ejemplares procedentes de Nuevo Méjico, U.S.A., Spizella wortheni ha sido posteriormente citado en ocho estados mejicanos, todos en el interior del noreste del país. Durante los últimos 30 años, todas las citas provienen de Coahuila y Nuevo León, y durante los últimos 1o exclusivamente de dos pequeñas áreas del sureste de Coahuila y del oeste de Nuevo León: parece que el área de distribución de esta escasamente conocida especie ha ido reduciéndose debido a una generalizada destrucción de su hábitat de matorral (mescal o yuca-enebro) pastizal. Se conoce muy poco de sus requerimientos específicos, movimientos locales, o incluso su distribución, y se propone que Spizella wortheni sea formalmente reconocido como una especie amenazada.

\section{Introduction}

Worthen's Sparrow Spizella wortheni is restricted to mesquite (or yucca)-juniper grassland in the interior of north-east Mexico, with one record (the type-specimen) coming from New Mexico, U.S.A. It was considered for inclusion in Threatened birds of the Americas (Collar et al. 1992) owing to an apparent lack of information concerning its distribution and status, but it was later confined to "near-threatened" status, adopted by BirdLife as a term for "birds which, while apparently not (yet) seriously in danger of global extinction, give cause for concern" (see Collar et al. 1992: 1047). However, it was agreed that this species, clearly a borderline case, warranted further investigation. This analysis was started during the final stages of compiling Threatened birds of the Americas, but its completion - and the conclusion that Worthen's Sparrow should in fact be considered threatened - did not occur until almost a year after the publication of that work.

Worthen's Sparrow has been recorded from eight Mexican states, although records in the last 30 years originate exclusively from a few localities in Coahuila 
and Nuevo León. The species is poorly known in most aspects of its ecology, and has received almost no attention from ornithologists since the 1950s. This neglect may in part be due to doubts cast over its taxonomic status by Burleigh and Lowery (1942), although these doubts appear to be unfounded.

Museums are referred to in the text by abbreviations as follows: AMNH, American Museum of Natural History; BMNH, British Museum of Natural History; CAS, California Academy of Sciences; CM, Carnegie Museum of Natural History; MCZ, Museum of Comparative Zoology (Cambridge, U.S.A.); MLZ, Moore Laboratory of Ornithology, Occidental College; MVZ, Museum of Vertebrate Zoology (Berkeley, U.S.A.); LSUMNS, Louisiana State University Museum of Natural Science; USNM, United States National Museum.

\section{Distribution}

Worthen's Sparrow is essentially endemic to the interior of north-east Mexico, although very little is known of its true distributional limits. Details of observations and specimen records from all the known localities are itemized in the Appendix and these localities are given in Figure 1 . The main centre of distribution (i.e. where breeding is known to have occurred) is in north-western Zacatecas, south-eastern Coahuila, western Nuevo León and south-western Tamaulipas. South of this area the species is known from lone records at sites in

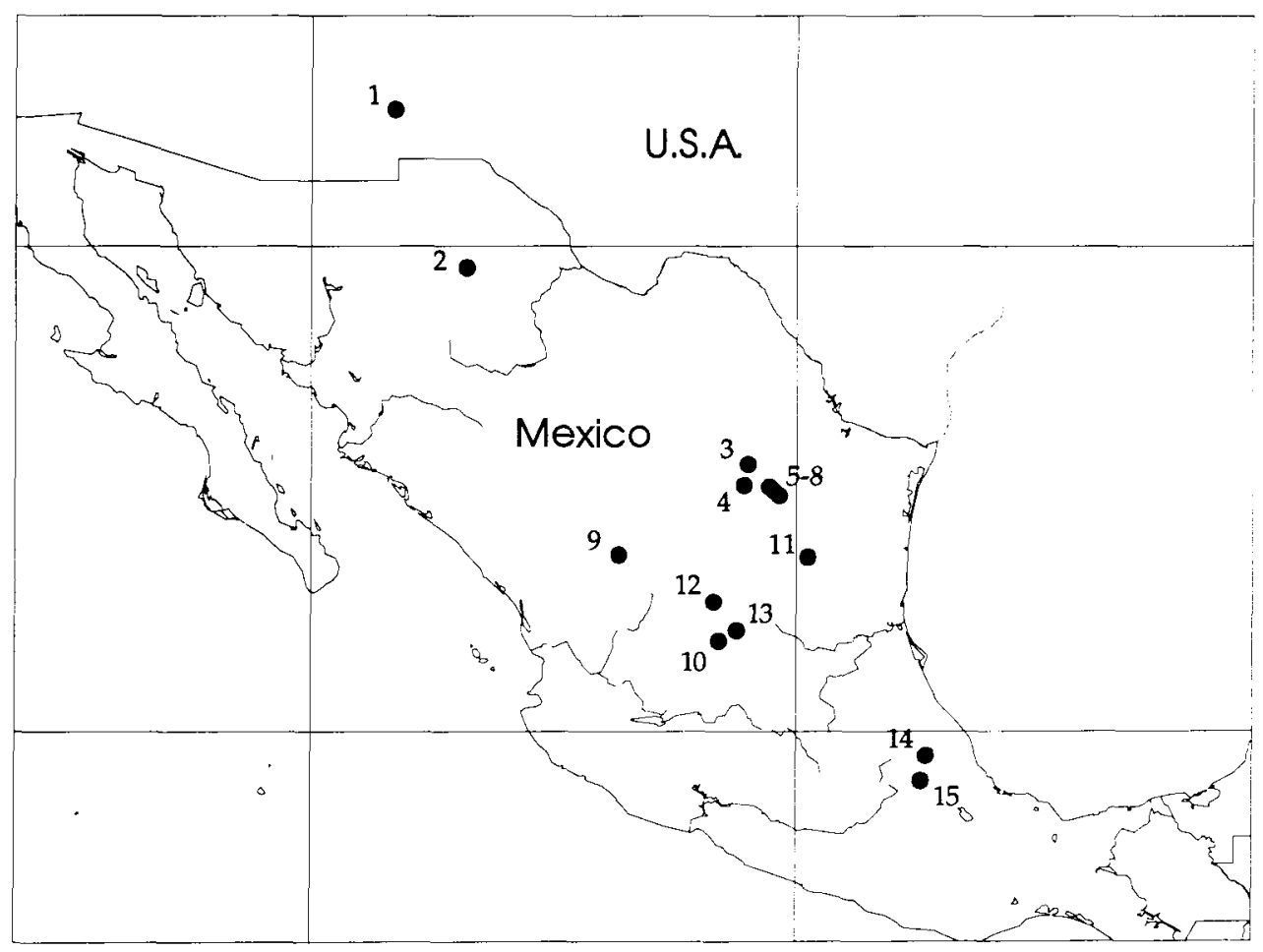

Figure 1. Distributional records of Worthen's Sparrow Spizella wortheni. Numbers correspond to the superscript numbers against sites in the Appendix. 
southern San Luis Potosí, south-eastern Zacatecas, northern Puebla and westcentral Veracruz, all of these records (six specimens at five localities) coming during the non-breeding season (for details of which see below).

AOU (1983) used this meagre evidence to suggest that the species is almost certainly a non-breeding migrant in the southernmost states, but although the bird moves locally during the non-breeding season in Coahuila and Nuevo León, it seems possible that the southern records may represent isolated (extirpated) populations (Howell and Webb in press).

The two records from the north-western part of Worthen's Sparrow's apparent range (Chihuahua, and New Mexico) both come from the height of the breeding season (i.e. mid-June), again suggesting isolated and possibly now extirpated populations, although AOU (1983), omitting the Chihuahua record, concluded that the New Mexico bird must have been "accidental".

\section{Status}

The total known historical range of Worthen's Sparrow embraces no more than $50,000 \mathrm{~km}^{2}$, although it is unknown what the extent of available habitat was or is within this range. In a 200 ha tract of homogeneous habitat (in Zacatecas), singing males were found to have an average territory size of 20-25 ha (Webster 1954, 1958), which gives an indication of the potential population of this species, and indeed historically it seems that Worthen's Sparrow was not uncommon (locally), although many localities at the periphery of its range are represented by lone (and often old) records, where there may have been subsequent local extirpations. Here we review the evidence state by state.

New Mexico The type-specimen (and only record from the U.S.A.) was collected in June 1884 (see Appendix), although the species was searched for unsuccessfully during three months' collecting in the vicinity of the type-locality in the early 1920s (Thayer 1925).

Chihuahua The species is only known from one record, in June 1959 (see Appendix).

Coahuila At and around the one site where Worthen's Sparrow has been recorded with any regularity (i.e. Tanque de Emergencia), observations are primarily of a flock or pairs totalling up to 12 birds, although in February 1986 several flocks were seen (precise numbers unknown), with an apparently exceptional $120+$ birds recorded (in flocks of $30-50$ birds) in November of the same year (see Appendix). This is the largest concentration of the species ever recorded, as were the individual flock sizes. However, only two (or perhaps a few more) pairs breed at this locality (A.M.S.) The species was recorded in 1941 from one other site, some $40 \mathrm{~km}$ north of Tanque de Emergencia (see Appendix).

Zacatecas In the north-western part of the state, north-west of Sombrerete, four pairs were recorded in 1952 (Webster and Orr 1954), with at least eight (possibly 10) pairs found in an area of c.200 ha during 1954 (Webster 1954, 1958). Two immatures were collected at this locality in August 1961, suggesting the con- 
tinued presence of a breeding population, but the species has not been recorded there since, despite a specific search in June 1991 (S.N.G.H.). There was one specimen collected in March 1942 at a site in south-eastern Zacatecas, close to the Jalisco border (see under that state below; also Appendix).

Nuevo León At least 40 birds were present in the fall and winter of 1986 between San Roberto and San Rafael (on Route 57, in the western part of the state), with a single flock of more than 1o near San Rafael in December 1986. The collection of birds in May and June (1959 and 1981 respectively) suggests the presence of a breeding population in this western region, although none could be found during fieldwork along Route 57 during August 1987, late March 1988 or April 1990 (A.M.S., S.N.G.H.).

San Luis Potosi The species is known from just three birds at two localities, with the last record in 1951 (see Appendix). A brief search at both of these sites in the summer of 1991 produced no further records (S.N.G.H.).

Tamaulipas Worthen's Sparrow was first recorded in the state during 1898 when a breeding population (of unknown size) was discovered (Ridgway 1901). In the 1922 breeding season 24 birds were collected, with 47 birds and six sets of eggs taken there two years later (Thayer 1925: see Appendix for specimen details). With this number of specimens being taken in the vicinity of one locality, there must have been a minimum population of $15^{-20}$ pairs. However, there have been no records in this state since that study.

Veracruz The species is only known from one record, in September 1948 (Lowery and Dalquest 1951).

Puebla The species is only known from one record, in April 1893 (see Appendix).

Jalisco Miller et al. (1957) suggested that a specimen collected near Ojuelos in March 1942 was attributable to this state; however, the specimen label (in MLZ) makes it clear that the bird originated from Zacatecas (see above).

\section{Ecology}

\section{Habitat}

Worthen's Sparrow is a bird of shrubby grassland between 1,200 and $2,400 \mathrm{~m}$, although details of its ecological requirements have only been recorded in two main areas, namely near Sombrerete in Zacatecas, and near Tanque de Emergencia in Coahuila. North-west of Sombrerete (near Cerro Gordo) the bird was found associated with the mesquite grassland near the pine-oak forest/mesquite grassland ecotone, between 2,350 and 2,450 $\mathrm{m}$ (Webster 1954). The ecotone was fairly abrupt between the open grassland in the valley (with a total absence of shrubs), and the dense oak woodland on the higher slopes of Cerro Gordo; the area comprised grassy pasture, spotted sparsely with low 
mesquite and scattered junipers (Webster 1954, Webster and Orr 1954). Shrubby junipers Juniperus deppeana were the chief woody plant, with individuals spaced 10-35 m apart, and averaging $2-3 \mathrm{~m}$ tall: a few sparse bare shrubs Garrya sp. (1-1.5 $\mathrm{m}$ tall) were evenly distributed with additional small mesquite Prosopis sp. (up to $1 \mathrm{~m}$ ) and some small Opuntia sp. and Pinus cembroides (Webster 1954). The ground-cover comprised numerous tufts of small shrubs $15-30 \mathrm{~cm}$ high, with no old grass: new grass started growing with the onset of the rains in June (Webster 1954).

The other main area of recent observations (A.M.S., S.N.G.H.) has been from around Tanque de Emergencia, south of Saltillo in south-eastern Coahuila. The species breeds at this locality and appears to be resident in the area (there are records from nine of 12 months). The valley at this site is divided by a fence: the north side is owned and managed by the Universidad Autonoma Agrícola Antonio Narro (UAAAN), and overgrazing is never allowed; in fact the pastures are essentially natural. Different pastures are given various grazing regimes, and the grass is always high in several of the pastures. The resultant vegetation north of the fence is yucca $Y u c c a \mathrm{sp}$. grassland with waist-high patches of juniper Juniperus sp.: bushes are common, with the yuccas being the tallest vegetation. The southern side of the fence is overgrazed shortgrass prairie, which may have been cleared at one time, since not even bushes grow there. A large population of the threatened Mexican prairie-dog Cynomys mexicanus is resident on this side of the fence. During the breeding season, Worthen's Sparrow appears to be almost exclusively found on the north side of the fence in the yucca-juniper grassland. Birds only enter the shortgrass (overgrazed) area to feed on the ground close to the fence. It is not known how important the shortgrass area is in providing the species's food requirements. In the nonbreeding season, like other Spizellae, Worthen's Sparrow forms flocks: these remain in the longer grass areas for the most part, but are often seen several hundred metres out into the overgrazed area. However, these birds when disturbed or flushed usually return to the high grass and bushes north of the fence (A.M.S., S.N.G.H). Closer to the village of Tanque de Emergencia, birds (up to 12 in March 1986) have been found in a habitat not recorded for the species elsewhere, with Larrea sp. and Leucophyllum sp. (more typical of desert areas) the dominant vegetation.

\section{Breeding}

Much like other Spizellae, Worthen's Sparrow forms winter flocks which at the onset of the breeding season break up into pairs (A.M.S.). In Coahuila, records suggest that the winter flocks break up by the end of March, although singing birds have not been noted until May (A.M.S.; see Appendix). The peak period for breeding activity (in Zacatecas) is between June and July, when the males are singing, pairs behave territorially, and nest-building has been observed (specimen labels in CAS). Nests with eggs (four clutches of four and two of three eggs have been recorded) have been collected from May to July (Thayer 1925), and immature birds are known from the middle of August (see Appendix).

In Zacatecas, breeding was noted in the sparse, low mesquite-juniper grass- 
land (see above: Webster 1954), with males (as they do elsewhere: A.M.S.) singing from waist-high bushes (Webster and Orr 1954). Similar habitat preferences were reported for species in the foothills around Miquihuana, Tamaulipas, where it was found breeding in prickly shrubs up to $1-1.5 \mathrm{~m}$ high (Thayer 1925). However, in this same area where the land had been cultivated for maize, Worthen's Sparrow was found breeding in overgrown fields, with the nests placed in low weeds (species of the mint family being identified), within $15 \mathrm{~cm}$ of the ground, or even resting on the ground (Thayer 1925).

\section{Non-breeding}

After the breeding season (or at least by the end of October), Worthen's Sparrow generally forms single-species winter flocks of up to $30-50$ birds, although approximately 10 birds in a flock seems to be more normal (see Appendix); single Vesper Sparrows Pooecetes gramineus and Clay-coloured Sparrows Spizella pallida have been recorded in Worthen's Sparrow flocks (S.N.G.H., A. Greensmith verbally 1993). In Coahuila and Nuevo León, the birds appear to move locally and form winter flocks in areas where they are uncommon (or even absent) in summer, thus perhaps moving (short) distances away from the nesting areas (S.N.G.H.; see Appendix); however, there is no adequate evidence that the species migrates over substantial distances as indicated in AOU (1983). Winter flocks disperse into pairs by the end of March (see above; also Appendix).

\section{Taxonomy}

In 1884 when the type-specimen of Worthen's Sparrow was collected, there seemed little doubt that it represented a full species, although Ridgway (1901) discussed its (possible) close relationship with Field Sparrow Spizella pusilla. The specific status of the taxon was not contended for nearly 60 years until Burleigh and Lowery (1942), in a lengthy discussion of the plumage characters and morphology of the specimens they had available, formally relegated the taxon to a subspecies of Field Sparrow. Webster and Orr (1954) disagreed with this treatment, and on collection of further material even described a new subspecies of Worthen's Sparrow, S. wortheni browni from western Zacatecas. They noted a number of plumage features that distinguish wortheni from pusilla, and were the first authors to notice a difference in vocalizations, suggesting that the song of Worthen's Sparrow is a cross between Eastern Field Sparrow S. pusilla pusilla and Chipping Sparrow S. passerina. This close affinity of the song to Chipping Sparrow has been reconfirmed by recent field observations (A.M.S. tape-recordings), and indeed, in certain plumage aspects Worthen's Sparrow is as close to Chipping as it is to Field Sparrow (S.N.G.H.). Another indication of the full species status of Worthen's Sparrow is that the eggs resemble those of Clay-coloured Sparrow more than those of Field Sparrow (Thayer 1925).

\section{Threats and conservation}

Worthen's Sparrow appears to have a specific breeding season requirement for mesquite-juniper or yucca-juniper grassland (the nesting in overgrown maize fields is seemingly exceptional: see above). This habitat type, much like the 
adjacent shortgrass prairie which is home to the threatened Mexican prairie-dog (Ceballos et al. 1993), has been greatly reduced owing to agriculture and grazing activities, and it seems unlikely that large tracts still exist within the centre of Worthen's Sparrow's present known distribution (A.M.S., Ceballos et al. 1993). From the evidence amassed here, Worthen's Sparrow was last recorded in New Mexico in 1884, Puebla in 1893, Tamaulipas in 1924, San Luis Potosí in 1951, Veracruz before 1957, Chihuahua in 1959, and in Zacatecas in 1961, thus leaving just Coahuila and Nuevo León with records during the 1980s and 1990s. For these reasons of habitat specificity, widespread habitat alteration and apparent range contraction, Worthen's Sparrow now demands formal recognition as a threatened species.

All recent records of Worthen's Sparrow come from the Coahuila/Nuevo León border region (see Appendix), although even this area has not escaped the progressive loss of habitat: availability of habitat has especially been reduced in the El Potosí valley, and suitable areas elsewhere have generally been modified through agriculture and erosion by cattle herding (Ceballos et al. 1993). Nevertheless, the fact that the species uses shortgrass prairie at all for foraging suggests that such habitat may be significant, so long as ungrazed areas are also present.

If Worthen's Sparrow is to survive in the long term, work is needed to determine its breeding and year-round feeding habitat requirements in more specific terms: this should be combined with a search for other nesting populations (the birds at Tanque de Emergencia currently represent the only known breeding population). The ecological requirements and local movements of winter flocks are also poorly understood and need to be clarified by close study before a full conservation strategy can be developed. Once the precise requirements are known, and the breeding localities have been clearly identified, protection and careful management of the habitat (to prevent clearance for agriculture or destruction by overgrazing) and nesting populations will be critical to the species's survival. It may be appropriate to consider the possible importance of certain native herbivore species in maintaining ecotones used by Worthen's Sparrow, and to investigate whether a link may exist between the decline of such herbivores and the decline of the sparrow. Meanwhile, however, the rotational grazing regime used by the UAAAN could perhaps be used as a model for management of known populations of Worthen's Sparrows where excessive grazing pressure is seen to be the primary threat.

\section{Acknowledgements}

We would like to extend our thanks to the following persons for providing specimen details from their museums: R. A. Sloss (AMNH), R. P. Prŷs-Jones (BMNH), J. B. Cunningham (CAS), K. C. Parkes (CM), J. V. Remsen (LSUMNS), R. A. Paynter (MCZ), J. R. Northern (MLZ), N. K. Johnson (MVZ), and M. R. Browning (USNM); to Alan Greensmith for details of his recent observations; and to Linda Birch (Edward Grey Institute Library) for her help with reference material. The initial data collection for this paper was undertaken as part of the BirdLife International (formerly ICBP) Red Data Book programme, and it was completed with the use of BirdLife facilities. 


\section{Appendix. Summary of all the known records of Worthen's Sparrow.}

Records are organized within country and state, from north-west to south-east; coordinates have been derived for every traced locality, which have been numbered and mapped in Figure 1; the coordinates are generally derived from the original source, from TAW (1986), OG (1956) or Ceballos et al. (1993): the coordinates for Limón, Veracruz, were taken from Lowery and Dalquest (1951). At least one source for each record is provided, and if specimens exist, the relevant museum (if known) is also given, as very often specimen label data complement the published information with more precise collecting dates and descriptions. The superscript number before each locality refers to the site number in Figure 1.

\begin{tabular}{|c|c|c|c|c|}
\hline State & Location/coord./Alt. (m) & Date & No. of birds & Source \\
\hline $\begin{array}{l}\text { New Mexico, } \\
\text { U.S.A. }\end{array}$ & $\begin{array}{l}{ }^{1} \text { Silver City, Grant County; } \\
32^{\circ} 47^{\prime} \mathrm{N} 108^{\circ} 16^{\prime} \mathrm{W}\end{array}$ & 16 June 1884 & $\begin{array}{l}1 \text { male } \\
\text { (type-specimen) } \\
\text { collected }\end{array}$ & $\begin{array}{l}\text { Ridgway } 1884, \\
\text { Deignan } 1961\end{array}$ \\
\hline Chihuahua & $\begin{array}{l}{ }^{2} \text { Cañón del Alamo, Sierra del } \\
\text { Nido; } 29^{\circ} 33^{\prime} \mathrm{N} 106^{\circ} 47^{\prime} \mathrm{W}\end{array}$ & 17 June 1959 & $\begin{array}{l}1 \text { female } \\
\text { collected }\end{array}$ & MVZ \\
\hline \multirow[t]{11}{*}{ Coahuila } & $\begin{array}{l}{ }^{3} \text { Saltillo (just outside city } \\
\text { limits) } 1,615 \mathrm{~m} ; 25^{\circ} 30^{\prime} \mathrm{N} \\
101^{\circ} \mathrm{oo}^{\prime} \mathrm{W}\end{array}$ & 16 April 1941 & $\begin{array}{l}1 \text { male collected } \\
\text { (two birds seen) }\end{array}$ & $\begin{array}{l}\text { Burleigh and } \\
\text { Lowery 1942, } \\
\text { LSUMNS }\end{array}$ \\
\hline & $\begin{array}{l}{ }^{4} \text { Tanque de Emergencia (c.6- } \\
7 \text { road } \mathrm{km} \text { east of }(\mathrm{c} .42 \mathrm{~km} \\
\text { south of Saltillo); } 25^{\circ} \mathrm{O}^{\prime} \mathrm{N} \\
101^{\circ} \mathrm{O} 4^{\prime} \mathrm{W}\end{array}$ & $\begin{array}{l}20 \text { September } \\
1961\end{array}$ & I bird collected & $\mathrm{CM}$ \\
\hline & & 24 June 1962 & I bird collected & $\mathrm{CM}$ \\
\hline & & February 1986 & $\begin{array}{l}\text { I bird collected; } \\
\text { several flocks } \\
\text { seen }\end{array}$ & A.M.S. \\
\hline & & 2 March 1986 & $\begin{array}{l}\text { c. } 12 \text { birds in a } \\
\text { flock }\end{array}$ & A.M.S. \\
\hline & & $\begin{array}{l}28 \text { November } \\
1986 \\
31 \text { May } 1987 \\
27 \text { March } 1988\end{array}$ & $\begin{array}{l}\text { c. } 120+\text { in flocks } \\
\text { of } 30-50 \text { birds } \\
4 \text { birds seen } \\
7 \text { or } 8 \text { birds in } \\
\text { pairs and } \\
\text { singles }\end{array}$ & $\begin{array}{l}\text { S.N.G.H. and } \\
\text { S. Webb } \\
\text { A.M.S. } \\
\text { S.N.G.H. and } \\
\text { S. Webb }\end{array}$ \\
\hline & & May 1988 & 3 birds seen & A.M.S. \\
\hline & & 5 April 1990 & $\begin{array}{l}9 \text { or } 10 \text { birds } \\
\text { seen }\end{array}$ & $\begin{array}{l}\text { S.N.G.H. and } \\
\text { S. Webb }\end{array}$ \\
\hline & & 9 May 1992 & $\begin{array}{l}4 \text { birds seen, } \\
2+\text { singing }\end{array}$ & A.M.S. \\
\hline & & January 1993 & $\begin{array}{l}\text { c. } 8 \text { birds in a } \\
\text { flock }\end{array}$ & A.M.S. \\
\hline & & 17 March 1993 & $\begin{array}{l}\text { c. } 12 \text { birds in a } \\
\text { flock }\end{array}$ & $\begin{array}{l}\text { A. Greensmith } \\
\text { verbally } 1993\end{array}$ \\
\hline Zacatecas & $\begin{array}{l}{ }^{9} \mathrm{C} .15 \mathrm{~km} \text { north-west of } \\
\text { Sombrerete (north-east of } \\
\text { Cerro Gordo) } 2,350-2,440 \mathrm{~m} \text {; } \\
23^{\circ} 38^{\prime} \mathrm{N} 103^{\circ} 40^{\prime} \mathrm{W}\end{array}$ & 19-21 June 1952 & $\begin{array}{l}\text { Male and } \\
\text { female } \\
\text { collected, } 3 \\
\text { singing males } \\
\text { and a female } \\
\text { present }\end{array}$ & $\begin{array}{l}\text { Webster and } \\
\text { Orr 1954, CAS }\end{array}$ \\
\hline
\end{tabular}




\begin{tabular}{|c|c|c|c|c|}
\hline & & June-July 1954 & $\begin{array}{l}\text { At least } 8 \\
\text { singing males } \\
\text { (1o breeding } \\
\text { pairs) } 3 \\
\text { specimens } \\
\text { collected }\end{array}$ & $\begin{array}{l}\text { Webster } 1954 \\
1958, \text { CAS }\end{array}$ \\
\hline & & 6-7 September & 3 birds present & Webster 1958 \\
\hline & & $\begin{array}{l}1955 \\
16 \text { August } 1961\end{array}$ & $\begin{array}{l}2 \text { immature } \\
\text { females } \\
\text { collected }\end{array}$ & CAS \\
\hline & $\begin{array}{l}{ }^{10} \text { Venta de las Amarillas } \\
(15 \mathrm{~km} \text { east of Ojuelos, Jalisco) } \\
2,040 \mathrm{~m} ; 21^{\circ} 52^{\prime} \mathrm{N} 101^{\circ} 35^{\prime} \mathrm{W}\end{array}$ & 11 March $194^{2}$ & I male collected & $\begin{array}{l}\text { MLZ (also } \\
\text { Miller et al. } \\
\text { 1957) }\end{array}$ \\
\hline \multirow[t]{4}{*}{ Nuevo León } & $\begin{array}{l}{ }^{5} \mathrm{Near} \text { San Rafael (Route } 57 \\
\text { between Saltillo and } \\
\text { Matehuala, } 84 \mathrm{~km} \text { from } \\
\text { Saltillo); } 25^{\circ} \mathrm{Oz}^{\prime} \mathrm{N} 100^{\circ} 33^{\prime} \mathrm{W}\end{array}$ & $\begin{array}{l}\text { 1 December } \\
1986\end{array}$ & $\begin{array}{l}\text { 10+ birds } \\
\text { present }\end{array}$ & $\begin{array}{l}\text { S.N.G.H. and } \\
\text { S. Webb }\end{array}$ \\
\hline & $\begin{array}{l}{ }^{6} \text { Los Pocitos, } 1.6 \mathrm{~km} \text { east of } \\
\text { (10 km north of San Roberto, } \\
\text { near Cerro Potosí); } 24^{\circ} 51^{\prime} \mathrm{N} \\
100^{\circ} 21^{\prime} \mathrm{W}\end{array}$ & 27 June 1981 & 1 male collected & $\begin{array}{l}\text { CM (tape- } \\
\text { recordings of } \\
\text { calls in Florida } \\
\text { State Museum) }\end{array}$ \\
\hline & $\begin{array}{l}{ }^{7} \text { Various stops between San } \\
\text { Roberto and San Rafael, on } \\
\text { Route } 57\end{array}$ & 24 October 1986 & $\begin{array}{l}\text { Total of } \mathrm{c} \cdot 40 \\
\text { birds }\end{array}$ & A.M.S. \\
\hline & $\begin{array}{l}{ }^{8} \mathrm{La} \text { Paz, } 25 \mathrm{~km} \text { south of }(\mathrm{km} \\
75 \text { on Route } 57) 1,950 \mathrm{~m}\end{array}$ & 4 May 1959 & $\begin{array}{l}\text { Male and } \\
\text { female collected }\end{array}$ & LSUMNS \\
\hline \multirow[t]{2}{*}{$\begin{array}{l}\text { San Luis } \\
\text { Potosí }\end{array}$} & ${ }^{12}$ Salinas; $22^{\circ} 40^{\prime} \mathrm{N} 101^{\circ} 42^{\prime} \mathrm{W}$ & $\begin{array}{l}\text { 30-31 March } \\
\text { 1951 }\end{array}$ & $\begin{array}{l}2 \text { females } \\
\text { collected }\end{array}$ & $\begin{array}{l}\text { LSUMNS (also } \\
\text { Miller et al. } \\
\text { 1957) }\end{array}$ \\
\hline & ${ }^{1.3}$ Tepetate; $22^{\circ} 05^{\prime} \mathrm{N}_{101}{ }^{\circ} 13^{\prime} \mathrm{W}$ & $\begin{array}{l}\text { 10 December } \\
1946\end{array}$ & $\begin{array}{l}\text { I specimen } \\
\text { collected }\end{array}$ & $\begin{array}{l}\text { LSUMNS (also } \\
\text { Miller et al. } \\
\text { 1957) }\end{array}$ \\
\hline Tamaulipas & $\begin{array}{l}{ }^{11} \text { Miquihuana; } 23^{\circ} 35^{\prime} \mathrm{N} \\
99^{\circ} 46^{\prime} \mathrm{W}\end{array}$ & $\begin{array}{l}\text { 8-9 June } 1898 \\
21 \text { June-10 July } \\
1922 \\
\text { June-July } 1924\end{array}$ & $\begin{array}{l}5 \text { males, one } \\
\text { female collected } \\
24 \text { birds } \\
\text { collected } \\
47 \text { birds } \\
\text { collected, } \\
\text { including six } \\
\text { nests (+eggs) }\end{array}$ & $\begin{array}{l}\text { AMNH, } \\
\text { USNM } \\
\text { AMNH, CAS, } \\
\text { CM, MVZ } \\
\text { Thayer } 1925 \\
\text { BMNH, MCZ }\end{array}$ \\
\hline Veracruz & $\begin{array}{l}{ }^{+} \text {Limón }(2 \mathrm{~km} \text { west of }) \\
2,285 \mathrm{~m} ; 19^{\circ} 30^{\prime} \mathrm{N} 97^{\circ} 21^{\prime} \mathrm{W}\end{array}$ & $\begin{array}{l}24 \text { September } \\
1948\end{array}$ & 1 bird collected & $\begin{array}{l}\text { Lowery and } \\
\text { Dalquest } 1951\end{array}$ \\
\hline Puebla & $\begin{array}{l}{ }^{15} \text { Chalchicomula (Ciudad } \\
\text { Serdán); } 18^{\circ} 59^{\prime} \mathrm{N} 97^{\circ} 27^{\prime} \mathrm{W}\end{array}$ & 28 April 1893 & I male collected & $\begin{array}{l}\text { USNM, } \\
\text { Ridgway 1901, } \\
\text { Miller et al. } \\
1957\end{array}$ \\
\hline
\end{tabular}




\section{References}

AOU (American Ornithologists' Union) (1983) Check-list of North American birds. Sixth edition. American Ornithologists' Union.

Burleigh, T. D. and Lowery, G. H. (1942) Notes on the birds of southeastern Coahuila. Occas. Pap. Mus. Zool. Louisiana State Univ. 12: 185-212.

Ceballos, G., Mellink, E. and Hanebury, L. R. (1993) Distribution and conservation status of prairie dogs Cynomys mexicanus and Cynomys ludovicianus in Mexico. Biol. Consero. 63: 105-112.

Collar, N. J., Gonzaga, L. P., Krabbe, N., Madroño Nieto, A., Naranjo, L. G., Parker, T. A. and Wege, D. C. (1992) Threatened birds of the Americas: the ICBP/IUCN Red Data Book. Cambridge, U.K.: International Council for Bird Preservation.

Deignan, H. G. (1961) Type specimens of birds in the United States National Museum. Bull. U.S. Natn. Mus. 221.

Howell, S. N. G. and Webb, S. (in press) A guide to the birds of Mexico and northern Central America. Oxford: Oxford University Press.

Lowery, G. H. and Dalquest, W. W. (1951) Birds from the state of Veracruz, Mexico. Univ. Kansas Publ. Mus. Nat. Hist. 3(4): 531-649.

Miller, A. H., Friedmann, H., Griscom, L. and Moore, R. T. (1957) Distributional checklist of the birds of Mexico, 2. Cooper Ornithological Society (Pacific Coast Avifauna 33).

OG (Office of Geography) (1956) Mexico: official standard names approved by the U.S. Board on Geographic Names. Washington, D.C.: Department of the Interior.

Ridgway, R. (1901) The birds of North and Middle America. Bull. U.S. Natn. Mus. 50(1).

Sada, A. M. (1987) Locations for finding Worthen's Sparrow (Spizella wortheni) in Nuevo León [Coahuila]. MBA Bulletin Board 1(87-3): 2.

TAW (1986) The Times atlas of the world. Comprehensive (seventh) edition with revisions. London: Times Books.

Thayer, J. E. (1925) The nesting of the Worthen [sic] Sparrow in Tamaulipas, Mexico. Condor 27: 34 .

Webster, J. D. (1954) Breeding bird census: mesquite grassland with scattered junipers. Audubon Field Notes 8: 376-377.

Webster, J. D. (1958) Further ornithological notes from Zacatecas, Mexico. Wilson Bull. 70: $243-256$.

Webster, J. D. and Orr, R. T. (1954) Summering birds of Zacatecas, Mexico, with a description of a new race of Worthen [sic] Sparrow. Condor 56: 155-160.

DAVID C. WEGE

BirdLife International, Wellbrook Court, Girton Road, Cambridge $\mathrm{CB}_{3}$ oNA, U.K.

\section{STEVE N. G. HOWELL}

Point Reyes Bird Observatory, 4990 Shoreline Highway, Stinson Beach, California 94970, U.S.A.

ANDRÉS M. SADA

Apdo Postal 1124, Monterrey, N.L. 6400o, Mexico 